BIOMEDICAL AND BIOSOCIAL ANTHROPOLOGY
$\begin{gathered}\text { Official Journal of the International Academy } \\ \text { of Integrative Anthropology } \\ \text { journal homepage: http://bba-journal.com }\end{gathered}$

\title{
Morphological changes in the tissues of the knee joints of rats in carrageenan-induced experimental arthritis
}

\section{Pelypenko O. V.}

Ukrainian Medical Stomatological Academy, Poltava, Ukraine

\section{ARTICLE INFO}

Received: 28 September 2020

Accepted: 22 October 2020

UDC: $616.728 .3-002$

CORRESPONDING AUTHOR e-mail: ovpelypenko@ukr.ne Pelypenko O. V.
Every fifth inhabitant of the earth has been diagnosed with osteoarthritis of various etiologies. Morphological studies of arthritis provide a theoretical basis for creating optimal treatments for this pathology. Given the polyetiological nature of the disease, the choice of the optimal experimental model, which would be as close as possible to the real conditions of inflammatory process reproduction, is the topical issue. The purpose of the study was to confirm the pathological reaction of the joint tissues of laboratory animals in response to intraperitoneal administration of ?-carrageenan. The study was performed on 50 white Wistar rats males aged 12 weeks, weighing 130-150 g. The animals were euthanized by an overdose of anaesthesia according to the terms of the study (1 - 30 days). Fragments of the distal metaepiphyses of the femur and proximal metaepiphyses of the tibia were used for histological examination. Staining of sections obtained on the microtome was performed with haematoxylin, eosin, and Van Gieson's stain. From the first day of the experimental study, a corresponding reaction of the joint tissues was being observed. Particularly pronounced were the changes in the synovial membrane in the form of oedema of the villi accompanied by an increased filling of blood vessels with foci of thrombosis. Gradually, up to 5 days in the synovial membrane, proliferative changes took place with a clear definition of the multilineage of the integumentary layer, vascular reaction with a tendency to thrombosis, in some places necrosis of synoviocytes was observed, but relative integrity of the morphological structure was still provided by protective barriers of bone and cartilage. On the 7th day pronounced resorption of both bone and cartilage tissue occurred, tissue structure became disorganized and functional layer became thin, accompanied by massive intracellular lysis. The process of synoviocytes necrobiosis with fatty degeneration spread. The histological picture of 10 days is characterized by generalized destruction of bone beams; the destroyed cartilage was replaced by granulation tissue with the presence of cavities. Massive foci of lymphocytic infiltration were observed in the synovial membrane. On the 14th day, a fragmentation of cartilage happened, most of the bone beams (trabeculae) were destroyed. After 3 weeks the morphological picture of cartilage tissue was determined by the appearance in the lacunae of viable cells, the number of which was close to normal. Bone beams were restored, although they remained thin. In a synovial membrane, the hyperplasia of apical departments of villi, leukocytes infiltration, disorganization of connective tissue, and separate vascular disturbances remained. 30 days of the experiment were characterized by a relative recovery of structural relationships to normal. The obtained data confirm the feasibility of using carrageenan in experimental studies of osteoarthritis.

Keywords: osteoarthritis, knee joint, rats, carrageenan.

\section{Introduction}

The reasons for the development of inflammatory and, as a consequence, degenerative-dystrophic changes of the joints are various, and therefore, scientists who perform experimental research, have a difficult choice of experimental techniques to obtain the most reliable data based on the objectives.

The available literature allows us to conclude that most studies are devoted to the study of the peculiarities of rheumatoid arthritis $[4,16,19]$. A large number of works are devoted to post-traumatic arthritis $[6,8,21]$. 
Nevertheless, in the general structure of diseases according to Alekseeva L. I. [1], a significant amount of cases are nonspecific idiopathic arthritis or arthritis caused by degenerative-dystrophic changes of the joint, as an exacerbation of a chronic process.

All these conditions have different etiopathogenesis, although a similar clinical picture, so the choice of adequate effective treatment is a topical problem.

Almost all drugs undergo preclinical studies in the context of creating appropriate biological experiments. Currently, the study of drug action in intact laboratory animals and experimental pathology is carried out following international standards, according to GLP (Good laboratory practice). The conditions of experimental research should meet state regulations on bioethics. Of course, these norms are humane and reflect the position of mankind concerning the ecology of the planet, but from the standpoint of scientific requirements, they significantly limit the informativeness of experimental sources.

However, to create a model of post-traumatic osteoarthritis, a large number of techniques have been proposed, which are based either on direct mechanical damage of the articular cartilage (or a complex of articular elements) or on creating joint instability with subsequent development of pathological changes. An overview of these techniques is covered in detail in the articles of Gromyko M. V. and Gritsuk A. I. [9] and Mc Coy A. M. [14]. The main feature of these experimental studies is the mandatory presence of significant energy applied to the joint or repeated (chronic) joint injury, which occurs in human society with a probability of only $12 \%$ [2].

To date, a large number of issues regarding metabolic osteoarthritis remain unresolved. The lack of understanding of the nature of the inflammatory process affecting the joint tissues, the polyvalence of pathological processes, the presence of a significant number of classifications of arthrological diseases make certain demands on experimental models of certain pathologies. The choice of the optimal model depends on many research-related factors, which are based on the capabilities of research centres, urgency, efforts of obtaining the desired results, increasing the reliability of data due to quantity, and taking into account situational features of immediate research tasks, etc $[17,22]$.

The most common model of experimental arthritis is an attempt to initiate rheumatoid arthritis by various methods. By definition, it is a systemic connective tissue disease with a predominant lesion of small joints with an erosive-destructive component of unknown aetiology with complex autoimmune pathogenesis. This state is achieved by the following methods: 1) the introduction of oil solutions (adjuvant induction); 2) introduction of autogenous solutions (collagen induction); 3) infectious induction. Often these techniques are combined. This model when used in the experiment on small animals provides a picture of chronic inflammation of the joints accompanied by the systemic response of the organism.
Each of these techniques has its advantages and disadvantages over each other. Complex procedure for antigen preparation, multicomponent administration of antigen, duration of the experiment due to the slow process of clinical manifestations of the disease (collagen-induced arthritis); the expressed bacteria-specific answer with development of acute inflammatory process (adjuvantinduced arthritis) does not always allow to receive the model corresponding for the experiment $[7,9]$.

The purpose of the study was to confirm the pathological reaction of the joint tissues of laboratory animals in response to the intraperitoneal administration of -carrageenan, followed by the use of experimental data to etermine the therapeutic effect of biologically active substances.

\section{Material and methods}

This paper presents a fragment of an experimental study performed on 50 white Wistar rats males aged 12 weeks, weighing 130-150 g, according to the current legislation, including the "Rules for the use of laboratory experimental animals", 1984 and the Helsinki Declaration of Humane attitude to animals.

There were 10 animals in the intact group, which, given the purity of the line of test samples, and, accordingly to the requirements for statistical reliability of the data were considered quite sufficient.

The experimental group consisted of 40 animals, which were simulated aseptic inflammation by intraperitoneal administration of $5 \mathrm{mg}$ of $\lambda$-carrageenan ("Sigma" USA) dissolved in $1 \mathrm{ml}$ of isotonic sodium chloride solution.

Animals were euthanized by an overdose of anaesthesia according to the terms of the study (1 - 30 days).

Histological material - fragments of the distal metaepiphyses of the femur and proximal metaepiphyses of the tibia - were fixed with $10 \%$ neutral formalin, after decalcification of bone tissue they were dehydrated in alcohols of increasing concentrations and immersed in paraffin. Staining of sections obtained on the microtome staining was performed with haematoxylin, eosin, and Van Gieson stains, followed by the study of the material using a microscope Biorex-3 BM-500T with a digital photomultiplier DCM 900 with programs adapted for these studies.

\section{Results}

From the first day of the experimental study, a corresponding reaction was observed in the joint tissues of the knee joints of rats. Changes in the synovial membrane in the form of inflammatory phenomena of the synovial membrane were especially pronounced. Significant oedema of the villi accompanied by increased filling of blood vessels with foci of thrombosis, mostly parietal, indicated the presence of an acute inflammatory process. Fragmentary defibering of collagen fiber groups in comparison with the intact group was also observed 


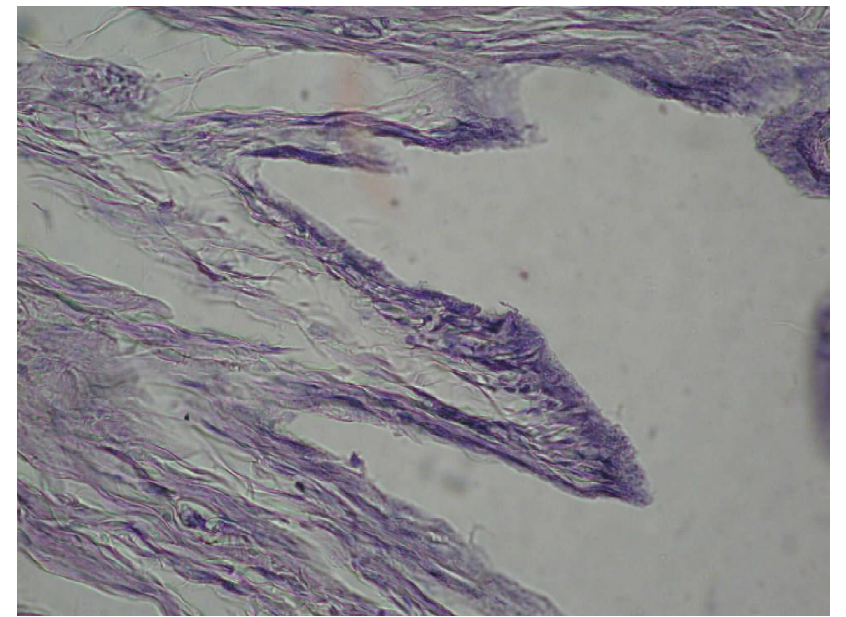

Fig. 1. Swelling of the villi of the synovial membrane. Hematoxylineosin. $x 400$.

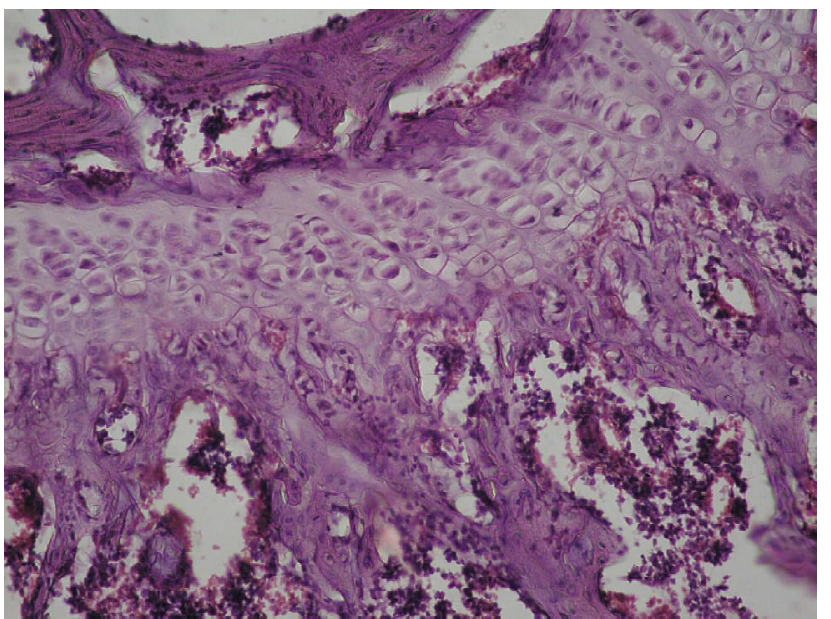

Fig. 2. Elements of chondrocyte pycnosis. Hematoxylin-eosin. $x 400$.

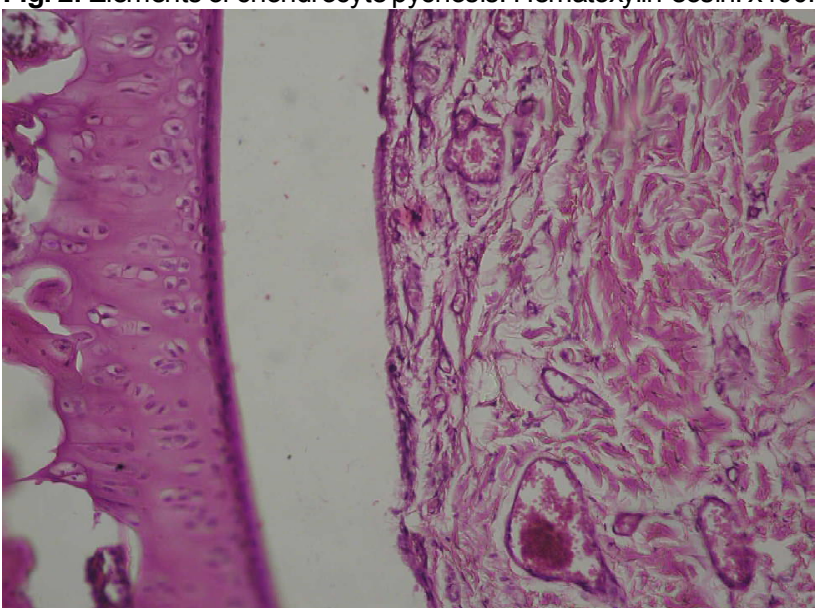

Fig. 3. Fragmentation of the integumentary layer of the synovial membrane. 5th day. Hematoxylin-eosin. x400.

(Fig. 1).

The histological picture of bone tissue did not differ from the norm, although the filling of blood vessels, especially the venous component, corresponded to the process of activation of anti-inflammatory mechanisms.
Articular cartilage retained a columnar structure, but near the subchondral bone were found elements of chondrocytes pyknosis with the formation of gaps (Fig. 2)

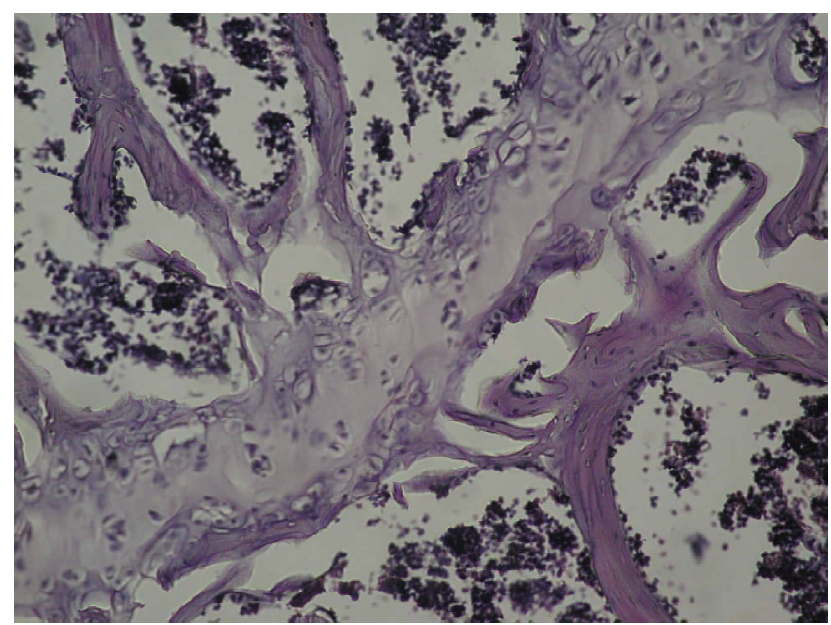

Fig. 4. Resorption of bone beams. 7th day. Hematoxylin-eosin. $\mathrm{x} 400$.

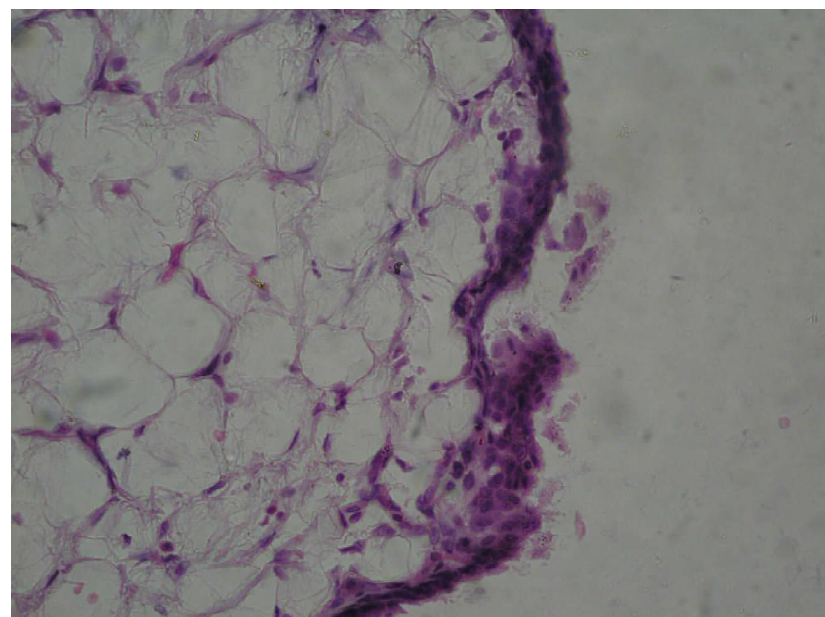

Fig. 5. Necrobiosis of synoviocytes. 7th day. Hematoxylin-eosin. $\mathrm{x} 400$.

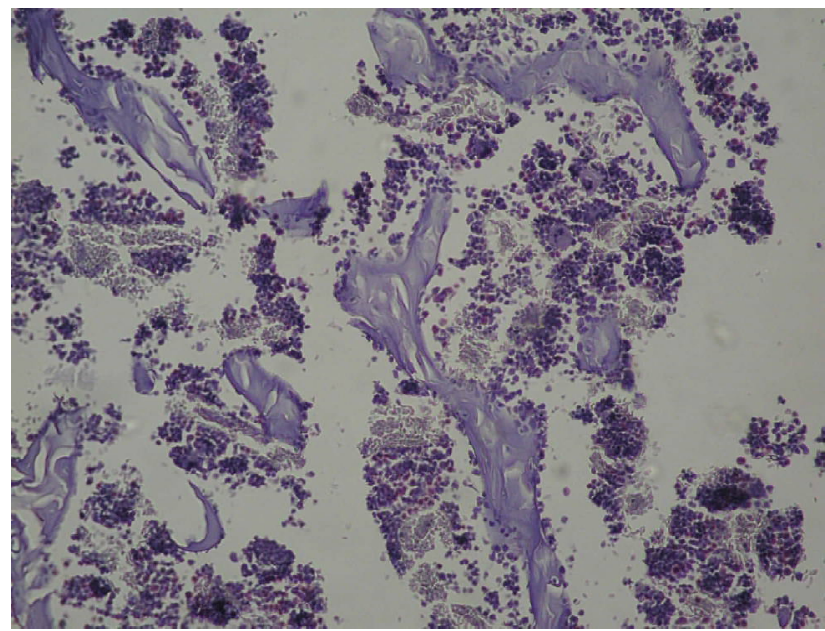

Fig. 6. Generalized destruction of bone tissue. 10th day. Hematoxylin-eosin. x400. 


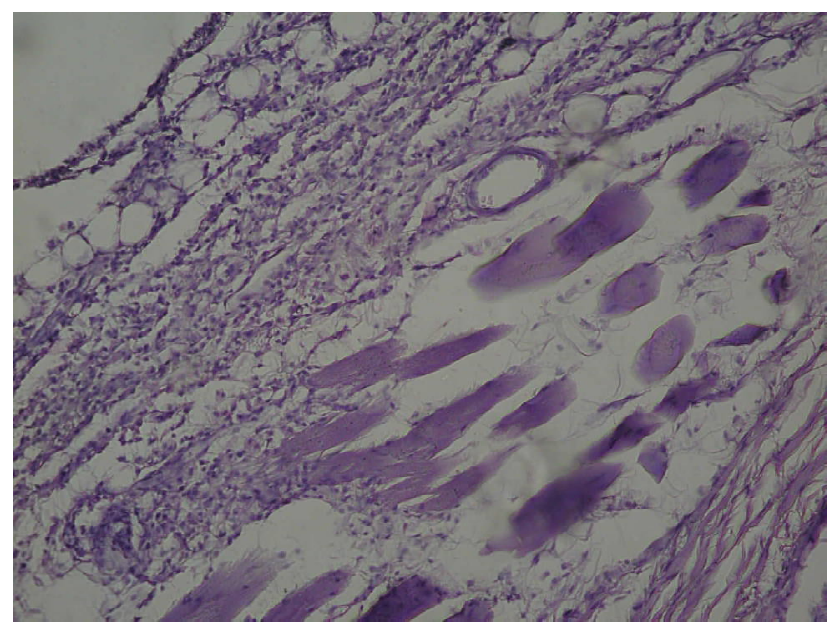

Fig. 7. Lymphocytic infiltration of the synovial membrane. 7th day. Hematoxylin-eosin. $x 400$.

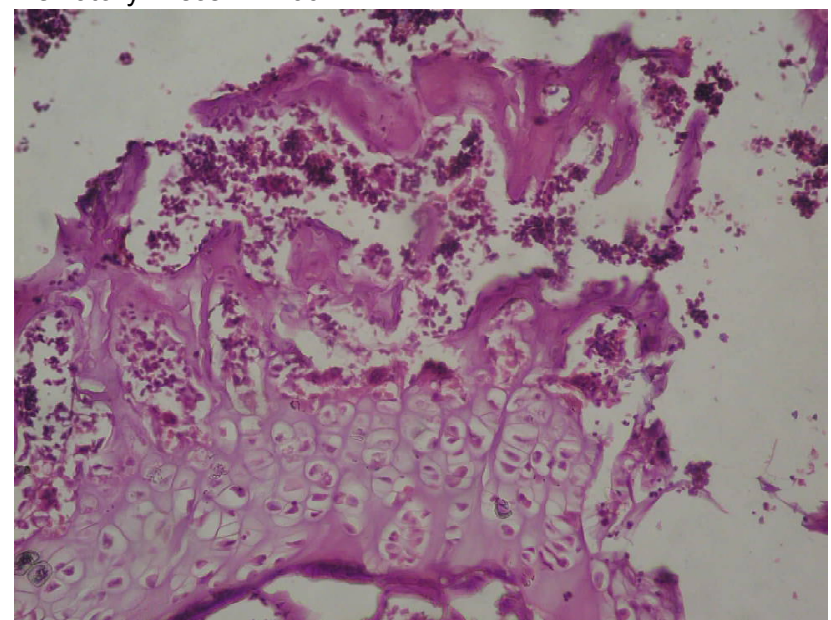

Fig. 8. Fragmentation of cartilage tissue. 14th day. Hematoxylineosin. $x 400$.

Gradually, up to 5 days in the synovial membrane, proliferative changes take place with a clear definition of the multilineage of the integumentary layer, vascular reaction with a tendency to thrombosis. In some place's necrosis of synoviocytes is observed, but relative integrity of the morphological structure is still provided by protective barriers of bone and cartilage (Fig.3).

Protective barriers of bone and cartilage also ensure the relative integrity of the morphological structure.

On the 7th day, there is pronounced resorption of both bone and cartilage tissue, the structure became disorganized, the thinning of the functional layer, and massive intracellular lysis occurred.

The process of necrobiosis of synoviocytes spreads, as evidenced by the foci of intracellular lysis with fatty degeneration (Fig. 4, 5).

The histological picture after 10 days is characterized by generalized destruction of bone trabeculae; the destroyed cartilage is replaced by granulation tissue with the presence of cavities.

Massive foci of lymphocytic infiltration are determined in the synovial membrane (Fig. 6, 7).

On the 14th day, there is a fragmentation of cartilage, most of the bone beams are destroyed. Massive pyknosis and karyolysis of chondrocytes are characteristic of this period.

In the synovial tissue the microcirculatory tract is dominated by the venous component, the vascular wall of the arterioles is thickened; there is lacunarity around the vessels, fragmentation of collagen fibers. The cover layer is thinned or absent in some places (Fig. 8).

After 3 weeks, the morphological picture of cartilage tissue is determined by the appearance in the lacunae of viable cells, the number of which is close to normal. Bone beams are restored, although they remain thin. From a synovial membrane the hyperplasia of apical departments of villi, infiltration by leukocytes, disorganization of connecting fabric, separate vascular disturbances remain.

On the 30 day of the experiment, a relative return of structural relationships to normal was observed.

\section{Discussion}

Another place in the reproduction of experimental osteoarthritis is occupied by chemically induced models, the advantages of which are the absence of the need for surgery, which denies the influence of the external infectious component of inflammation; ease of manipulation; the short time of obtaining results, which is of particular importance when performing short-term research. The special significance of these minimally invasive techniques lies in the approximation to the real conditions of development of the inflammatory process of the joint in humans and, most importantly, the possibility of using this model for purely therapeutic intervention [12].

It should be noted that the chemicals that are mostly used for the reproduction of experimental arthritis (talc, turpentine, formalin, etc.) do not reflect the real picture of the disease due to the impossibility of them penetrating the joint under real conditions. In this regard, substances with a probable effect on joint tissues met in everyday life or during treatment are of great interest to scientists whose work is focused on practical experience [11, 17]

A special place in these conditions is occupied by experimental studies of participation in the homeostasis of $\lambda$-carrageenan - a substance that in a certain concentration is found in high demand foods, used in industry as a preservative, and registered as a food additive E 407. As stabilizer carrageenan, is also used in the production of household chemicals (toothpaste, hair-gels, and air fresheners). Most experimental studies of the biological activity of carrageenan are devoted to its participation in the development of pathological changes in the gastrointestinal tract; however, there is a large amount of work that indicates a significant effect of carrageenan on the functioning of other systems and organs. The presence of inflammatory processes in the experiment was found in laboratory animals also in the liver, salivary glands, joint 
tissues [15]

The study of the last localization was first reliably confirmed in the works of Levy L. [13]. Reproduction of experimental arthritis was performed by intraplantar administration of $1 \%$ carrageenan solution. Sugishita $E$. in 1981 described the acute phase of mouse paw oedema using a $3 \%$ solution of carrageenan. Subsequent studies of scientific heirs have proven the existence of a sequence of development of two phases of the acute inflammatory process in paraarticular tissues [10, 20, 23].

Intraplantar administration of carrageenan is used to create conditions for the study of inflammatory processes of the extremities at the present stage $[5,18]$.

The effect of carrageenan on the functional components of the joint due to changes in the general condition of the body is isolated. Most scientists consider the reaction of the joint tissues as a reproduction of the model of rheumatoid arthritis, which causes a reason for discussion. Violation of homeostasis, caused by the introduction of an active substance of a certain concentration, is naturally reflected in the form of functional changes in highly

\section{References}

[1] Alekseeva, L. I., Taskina, E. A., \& Kashevarova, N. G. (2019). Osteoarthritis: epidemiology, classification, risk factors, and progression, clinical presentation, diagnosis, and treatment. Modern Rheumatology Journal, 13(2), 9-21. doi: 10.14412/ 1996-7012-2019-2-9-21

[2] Bailey, K. N., Furman, B. D., Zeitlin, J., Kimmerling, K. A., Wu, C. L., Guilak, F., \& Olson S. A. (2020). Intra-articular depletion of macrophages increases acute synovitis and alters macrophage polarity in the injured mouse knee. Osteoarthritis and cartilage, 28(5), 626-638. doi: 10.1016/j.joca.2020.01.015

[3] Bittencourt, J. A., Neto, M. F., Lacerda, P. S., Bittencourt, R. C., Silva, R. C., Lobato, C. C., ... Santos, C. B. (2019). In Silico Evaluation of Ibuprofen and Two Benzoylpropionic Acid Derivatives with Potential Anti-Inflammatory Activity. Molecules, 24(8), 1476. doi: 10.3390/molecules24081476

[4] Buch, M. H, Eyre, S., \& McGonagle D. (2021). Persistent inflammatory and non-inflammatory mechanisms in refractory rheumatoid arthritis. Nat Rev Rheumatol, 17(1), 17-33. doi: 10.1038/s41584-020-00541-7

[5] Cordeiro, M. S., Simas, D. L., Perez-Sabino, J. F., Merida-Reyes, M. S., Munoz-Wug, M.A., Oliva-Hernandez, B. E., ... Giorno, T. (2020). Characterization of the Antinociceptive Activity from Stevia serrata. Cav. Biomedicines, 8(4), 79. doi: 10.3390/ biomedicines 8040079

[6] Delco, M. L., Kennedy, J. G., Bonassar, L. J., \& Fortier, L. A. (2017). Post-traumatic osteoarthritis of the ankle: A distinct clinical entity requiring new research approaches. $J$ Orthop Res, 35(3), 440-453. doi: 10.1002/jor.23462

[7] Gaynetdinova, A. N., Zalyalyutdinova, L. N., Abdulganieva, D. I., Imanaeva, A. Ya., \& Gayfullin, A. N. (2015). Экспериментальное обоснование применения тиоктовой кислоты с метотрексатом в комбинированной терапии ревматоидного артрита на модели адъювантного артрита [Experimental basis of thioctic acid addicton to methotrexate in combined therapy of rheumatoid arthritis by adjuvant arthritis model]. Инновационные технологии в медицине - Innovative technologies in medicine, 4(89), 19-23.

[8] Golovach, I. Y., \& Yehudina, Y. D. (2019). Posttraumatic sensitive tissues, which certainly include tissues that form the elements of the musculoskeletal system, especially the most mobile [3].

These data served as a basis for choosing the use of $\lambda$-carrageenan to reproduce a model of experimental nonspecific knee arthritis.

Our experimental study showed that intraperitoneal administration of certain concentrations of carrageenan causes pathological changes of an inflammatory nature in the joint tissues. Manifestations of nonspecific arthritis gradually increase up to 14 days, followed by restoration of morphological structure up to 30 days. Early manifestations of inflammation, as well as residual changes, are most characteristic of the synovial tissue of the joint.

\section{Conclusions}

The obtained data confirm the expediency of intraperitoneal administration of $\lambda$-carrageenan in experimental studies to reproduce a model of nonspecific arthritis of the knee joints.

osteoarthritis: contemporary views of development, progression and therapeutic approaches. Политравма Polytrauma, (1), 82-89.

[9] Gromyko, М. V., \& Gritsuk A. І. (2012). Экспериментальные модели ревматоидного артрита [Experimental models of rheumatoid arthritis]. Проблемы здоровья и экологии - Health and Ecology Issues, 2(32), 115-118.

[10] Henriques, M. G., Silva, P. M., Martins, M. A., Flores, C. A., Cunha, F. Q., Assreuy-Filho, J., \& Cordeiro, R. S. (1987). Mouse paw oedema. A new model for inflammation?. Braz. J. Med. Biol. Res., 20(2), 243-249. PMID: 3690058

[11] Hladkykh, F. V., Student, V. O., Stepaniuk, N. H., \& Vernyhorodskyi, S. V. (2017). Патоморфологическое и компьютерное томографическое исследование влияния ибупрофена и его комбинации с 2-фенил-3-карбетокси-4диметиламино-метил-5-оксибензофурана гидрохлоридом (винбороном) на состояние суставов нижних конечностей крыс с экспериментальным ревматоидным артритом [Pathomorphological and computerized tomography study of ibuprofen and combination with 2-phenyl-3-carbethoxy-4dimethylaminomethyl-5-oksibenzofuran hydrochloride (vinboron) influence on the joints of lower extremities of rats with experimental rheumatoid arthritis]. Фармация и фрармакология - Pharmacy \& Pharmacology, 5(5), 457-486. doi: 10.19163/2307-9266-2017-5-5-457-486

[12] Kuyinu, E. L., Narayanan, G., Nair, L. S., \& Laurencin, C. T. (2016). Animal models of osteoarthritis: classification, update, and measurement of outcomes. J Orthopaedic Surg Res, (11), 19. doi: 10.1186/s 13018-016-0346-5

[13] Levy, L. (1969). Carrageenan paw edema in the mouse. Life Sci, 8(11), 601-606. doi: 10.1016/0024-3205(69)90021-6

[14] McCoy, A. M. (2015). Animal Models of Osteoarthritis: Comparisons and Key Considerations. Vet. Pathol, 52(5), 803818. doi: $10.1177 / 0300985815588611$

[15] Muzhikyan, A. A., Shekunova, E. V., Kashkin, V. A., Makarova, M. N., \& Makarov, V. G. (2018). Histological evaluation of joint pathology in various models of chronic arthritis in rats. Laboratory Animals for Science, 1, 32-45. doi: 10.29926/ 


\section{X-2018-01-04}

[16] Nasonov, E. L. (2017). Фармакотерапия ревматоидного артрита: новая стратегия, новые мишени [Pharmacotherapy for rheumatoid arthritis: new strategy, new targets]. Научно-практическая ревматология Rheumatology Science and Practice, 55(4), 409-419. doi: 10.14412/1995-4484-2017-409-419

[17] Nosivets, D. S. (2019). Экспериментальные модели патологии хрящевой ткани [Experimental models of cartilage tissue pathology]. Запорожский медицинский журнал Zaporozhye medical journal, 21(4), 554-560. doi: 10.14739/ 2310-1210.2019.4.173362.

[18] Pelypenko, A. V., Shepitko, V. I., \& Pelypenko, L. B. (2019). Morphofunctional characteristics of a microcirculatory beds subchondral bone at the introduction of cryo-conversed placenta on the background of aseptic inflammation in the rat. World of medicine and biology, 2(68), 187-191. doi: 10.26724/ 2079-8334-2019-2-68-187-191

[19] Ponyk, R. M., \& Korytko, Z. I. (2019). Захворюваність та особливості реабілітації хворих на ревматоїдний артрит в умовах сьогодення [Disease and peculiarities of rehabilitation of patients with rheumatoid arthritis in the present time]. Здобутки клінічної і експериментальної медицини
- Achievements of Clinical and Experimental Medicine, (3), 183-187. doi: 10.11603/1811-2471.2019.v.i3.10504

[20] Posadas, I., Bucci, M., Roviezzo, F., Rossi, A., Parente, L., Sautebin, L., \& Cirino, G. (2004). Carrageenan induced mouse paw oedema is biphasic, age weight dependent and displays differential nitric oxide cyclooxygenase 2 expression. British Journal of Pharmacology, 142(2), 331-338. doi: 10.1038/ sj.bjp.0705650

[21] Punzi, L., Galozzi, P., Luisetto, R., Favero, M., Ramonda, R., Oliviero, F., \& Scanu, A. (2016). Post-traumatic arthritis: overview on pathogenic mechanisms and role of inflammation. RMD Open, 2(2), e000279. doi: 10.1136/rmdopen-2016000279

[22] Shepitko, V. I., \& Pelypenko, O. V. (2015). Сучасні погляди на структурну організацію суглобових тканин [Current concepts of the structural organization of joint tissues]. Свim медицини та біології - World of medicine and biology, 3(52), 175-183.

[23] Sugishita, E., Amagaya, S., \& Ogihara, Y. (1981). Antiinflammatory testing methods: comparative evaluation of mice and rats. J. Pharmacobiodyn, 4(8), 565-575. doi: 10.1248/ bpb1978.4.565 